\title{
Zasady przeprowadzania strategii wyszukiwania na potrzeby raportów HTA
}

\author{
Konrad Pirek ${ }^{1}$ \\ Tomasz Garbaty ${ }^{2}$ \\ Marta Owczarek ${ }^{2}$
}

\begin{abstract}
${ }^{1}$ Dział Programów Lekowych, Wydział Oceny Technologii Medycznych, Agencja Oceny Technologii Medycznych i Taryfikacji

${ }^{2}$ Dział Chemioterapii, Wydział Oceny Technologii Medycznych, Agencja Oceny Technologii Medycznych i Taryfikacji
\end{abstract}

Adres do korespondencji: Konrad Pirek, Dział Programów Lekowych, Wydział Oceny Technologii Medycznych, Agencja Oceny Technologii Medycznych i Taryfikacji, ul. Przeskok 2, 00-032 Warszawa, sekretariat@aotm.gov.pl

\section{Abstract}

\section{Literature search strategy for Health Technology Assessment Reports}

Preparation of HTA reports requires access to the latest and most reliable knowledge in the field of health care. Systematic reviews are the basic tools used to obtain it. In order to find the literature necessary for a systematic review, search strategies are performed in databases. With their help it is possible to thoroughly and reliably search the resources of individual databases and find the required information. Properly executed search strategies also reduce the risk of missing valuable publications. During the preparation of the search strategy, one should use the tools and additional functions implemented in individual databases, thanks to which it is possible to strictly control the process and adapt it to your own needs. Performing a search strategy is a basic skill for anyone who prepares HTA reports.

\section{Key words: search strategy, systematic review, database, HTA}

Slowa kluczowe: strategie wyszukiwania, przegladily systematyczne, bazy danych, HTA

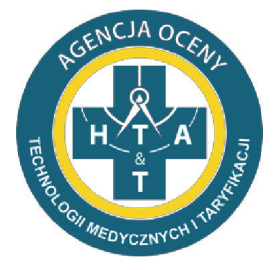

\section{AGENCJA OCENY TECHNOLOGII MEDYCZNYCH I TARYFIKACJI}

\section{Wstẹp}

Systematyczne wyszukiwanie informacji i przygotowanie na ich podstawie przeglądu systematycznego literatury jest stałym elementem pracy nad każdym raportem z zakresu oceny technologii medycznych (ang. Health Technology Assessment, HTA) lub medycyny opartej na dowodach (ang. Evidence-Based Medicine, EBM). Źródłem najnowszych i wiarygodnych informacji naukowych są publikacje $\mathrm{z}$ recenzowanych czasopism naukowych, których zawartość można wyszukiwać

\section{Rzeczpospolita \\ Fundusz Spójności

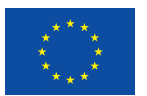

w przeznaczonych do tego celu bazach danych (między innymi Medline, Embase i Cochrane Library).

Celem przeprowadzania strategii wyszukiwania jest odnalezienie w bazie danych wszystkich zamieszczonych w niej materiałów dotyczących interesującego nas tematu. W związku z tym przed przystąpieniem do samego przeszukiwania poszczególnych baz danych należy określić, w jaki sposób będziemy te informacje wyszukiwali. W niniejszym artykule zostaną przedstawione zasady przygotowywania oraz wykonywania strategii wyszukiwania i przeglądów systematycznych literatury 
na potrzeby raportów HTA na przykładzie baz danych PubMed, Embase i Cochrane Library. Należy jednak zwrócić uwagę, iż przedstawione zasady znajdą zastosowanie również $\mathrm{w}$ pozostałych bazach danych publikacji naukowych.

Omówione zostaną podstawowe kroki i narzędzia konieczne do przygotowania czułych i swoistych strategii wyszukiwania, w tym: przygotowanie schematu PICO (ang. Population, Intervention, Comparison, Outcome), rodzaje wyszukiwania, operatory logiczne i znaki specjalne oraz filtry. Przedstawione zostaną również najczęściej spotykane problemy i możliwości ich rozwiązania. Dodatkowo zamieszczono również propozycje filtrów do zastosowania w poszczególnych bazach danych, pozwalających na wyszukiwanie specyficznych zbiorów danych (między innymi typy publikacji, rodzaje badań, linie leczenia, specyficzne subpopulacje: wiek, rasa, płeć).

\section{Biomedyczne bazy danych}

Poniżej przedstawiono krótki opis podstawowych baz danych wykorzystywanych w Agencji Oceny Technologii Medycznych i Taryfikacji (AOTMiT) do przygotowywania raportów HTA.

\section{Medline}

To podstawowa baza danych zawierająca dowody naukowe z najważniejszych czasopism biomedycznych. Dostęp jest darmowy. Do korzystania z niej wystarczy dostęp do Internetu. Medline należy do US National Library of Medicine, która jest częścią National Institutes of Health (NIH) - jednej z instytucji podlegających Ministerstwu Zdrowia i Pomocy Humanitarnej Stanów Zjednoczonych. Funkcjonowanie bazy danych Medline jest finansowane ze środków budżetowych USA. Darmowy dostęp do tej bazy danych jest realizowany za pomocą platformy PubMed (https://www.ncbi.nlm.nih.gov/ pubmed/). Aktualnie w bazie danych Medline jest zaindeksowanych około $29 \mathrm{mln}$ publikacji biomedycznych i ich liczba systematycznie rośnie. Nowe publikacje dodawane są każdego dnia (w 2018 roku dodano łącznie 904636 pozycji). W bazie znajdują się publikacje z około 5200 czasopism wydawanych w przeszło 40 językach. Medline posiada również własny słownik haseł Medical Subject Headings (MeSH). W swojej pierwotnej postaci została założona w 1964 roku jako baza biblioteczna MEDical Literature Analysis and Retrieval System [1].

\section{Embase}

Baza danych zawierająca dowody naukowe (abstrakty) z większości czasopism biomedycznych. Dostęp do niej jest płatny. Możliwe jest wykupienie dostępu indywidualnego oraz w ramach konsorcjum kilku zainteresowanych podmiotów. Baza danych jest prowadzona przez wydawnictwo Elsevier. Obecnie w bazie danych Embase jest zaindeksowanych około $32 \mathrm{mln}$ publikacji (w tym cała baza Medline) i ich liczba systematycznie rośnie. Każdego roku dodawanych jest około 1,5 mln nowych publikacji. W bazie znajdują się publikacje z około 8500 czasopism (w tym 2900 czasopism indeksowanych tylko w Embase) wydawanych w 95 krajach. Dodatkowo w Embase zamieszczane są również materiały konferencyjne: około 2,4 mln abstraktów pochodzących z 7000 konferencji, najstarsze z 2009 roku. Baza danych posiada własny słownik Emtree. Najstarsze indeksowane publikacje pochodzą z 1947 roku [2].

\section{Cochrane Library}

Baza danych, w której zamieszczone są publikacje dotyczące zagadnień z zakresu szeroko pojętej opieki zdrowotnej. Dostęp do niej jest płatny. Właścicielem bazy danych jest Cochrane - niezależna międzynarodowa organizacja typu non profit. Została ona założona w 1993 roku pod nazwą Cochrane Collaboration. Celem bazy danych jest dostarczanie wysokiej jakości dowodów naukowych wspierających podejmowanie racjonalnych decyzji z zakresu opieki zdrowotnej opartych na zasadach EBM. W jej skład wchodzą: Cochrane Database of Systematic Reviews (CDSR), Cochrane Central Register of Controlled Trials (CENTRAL) oraz Cochrane Clinical Answers. W trakcie przeprowadzania strategii wyszukiwania zasoby powyższych baz są przeszukiwane jednocześnie. Obecnie w bazie danych Cochrane Library znajduje się około $2 \mathrm{mln}$ zindeksowanych rekordów. Baza Cochrane ma zaimplementowany słownik MeSH, który jest również wykorzystywany w bazie Medline [3].

\section{Zasady tworzenia strategii wyszukiwania oraz przeglallów systematycznych na podstawie odnalezionych wytycznych metodologicznych}

\section{Zasady tworzenia przeglądu systematycznego z uwzględnieniem PICO}

\section{Prace wstępne}

Zdaniem Murada i wsp. [4] wyniki przeglądu systematycznego „stanowią odpowiedź na precyzyjnie sformułowane pytanie kliniczne udzieloną w ustrukturyzowany, odtwarzalny sposób".

$\mathrm{Na}$ proces tworzenia przeglądu systematycznego składa się osiem lub dziewięć kroków:

1. sformułowanie pytania klinicznego według schematu PICO:

- P: rozpoznanie choroby (ang. patient's diagnosis) lub populacja włączona do badania (ang. population);

- I: interwencja lub leczenie zastosowane w grupie badanej (ang. intervention);

- C: komparator lub leczenie zastosowane w grupie kontrolnej (ang. comparison or control intervention);

- O: punkt końcowy badania (ang. outcome);

2. określenie klinicznych $(\Rightarrow$ PICO) oraz metodologicznych kryteriów włączania badań do przeglądu systematycznego;

3. sformułowanie hipotezy a priori, przybliżającej do wyjaśnienia niejednorodności wyników badań;

4. wyczerpujący przegląd piśmiennictwa; 
5. wstępna ocena streszczeń znalezionych badań;

6. kwalifikacja badań (na podstawie oceny treści manuskryptów);

7. ocena badań pod względem ich wiarygodności (ryzyka zaistnienia błędów systematycznych - bias);

8. ekstrakcja danych;

9. przeprowadzenie metaanalizy (co nie zawsze jest możliwe lub właściwe) [3, 4].

Analiza problemu decyzyjnego pozwala poprawnie zbudować kryteria włączania badań do analizy według schematu PICO: P - populacja, w której dana interwencja będzie stosowana; I - proponowana interwencja; C proponowane komparatory; O - efekty zdrowotne, czyli punkty końcowe, według których będzie oceniana efektywność kliniczna. Czasami do schematu PICO dodaje się dodatkowy człon S (ang. study), w ramach którego określa się rodzaj badań uwzględnianych w przeglądzie. Powstaje wtedy schemat PICOS. Rodzaj badań włączanych do analiz zależy od charakteru przeprowadzanej analizy [5].

\section{Cechy „dobrego" przeglądu systematycznego}

Celem przeglądu systematycznego jest odnalezienie, selekcja oraz krytyczna ocena badań, które to zadania mają na celu znalezienie odpowiedzi na jasno sformułowane pytanie. Przegląd systematyczny powinien być przeprowadzany zgodnie $\mathrm{z}$ predefiniowanym protokołem. Polega on na przeprowadzeniu kompleksowego i przejrzystego wyszukiwania w wielu bazach danych oraz „szarej literaturze”. Wyszukiwania te mogą być odtworzone przez innych badaczy. W ramach przeglądu systematycznego konieczne jest przygotowanie dobrze przemyślanej strategii wyszukiwania, której zadaniem jest znalezienie ściśle określonych informacji lub odpowiedzenie na jasno sformułowane pytanie. W przeglądzie systematycznym powinny znaleźć się informacja na temat rodzaju poszukiwanych badań, ich krytycznej oceny, nazwy przeszukanych baz danych, daty przeszukiwania, czasu, z jakiego włączano publikacje, użytych kwerend wyszukiwania oraz sposobu filtrowania (jeżeli korzystano z filtrów).

Siedem podstawowych cech przeglądu systematycznego to:

1. transparentność;

2. przejrzystość;

3. kompleksowość;

4. skupienie;

5. jednolitość;

6. dostępność;

7. objęcie całego tematu $[6,10]$.

\section{Selekcja informacji}

Proces weryfikacji mający na celu ocenę, czy odnalezione doniesienia naukowe spełniają kryteria włączenia do analizy, należy przeprowadzić etapowo. Pierwszy etap obejmuje selekcję na podstawie tytułów i streszczeń, a dalsze - sa oparte na pełnych tekstach publikacji. Selekcja badań powinna być dokonywana na podstawie przyjętych przed rozpoczęciem wyszukiwania kryteriów włączenia i wyłączenia, zgodnych ze zdefiniowanym schematem PICO. W sytuacji gdy populacja docelowa zdefiniowana na etapie analizy problemu decyzyjnego nie odpowiada próbie ocenianej w odnalezionym materiale dowodowym, dopuszcza się przeprowadzenie analizy klinicznej w populacji zbliżonej do docelowej. W takim wypadku należy przedyskutować potencjalny wpływ różnic między populacjami na wyniki uzyskane w analizie klinicznej. W procesie selekcji należy wyróżnić doniesienia naukowe stanowiące podstawę oceny efektywności eksperymentalnej i praktycznej. Selekcja badań pierwotnych powinna dotyczyć publikacji w językach: angielskim, polskim, a w uzasadnionych przypadkach - także w innych. Szczegółowe etapy postępowania w selekcji i włączaniu badań do analizy skuteczności eksperymentalnej i praktycznej zaprezentowano na Rysunku 1.

$\mathrm{Na}$ wszystkich etapach selekcja badań w ramach przeglądu systematycznego powinna być wykonywana przez co najmniej dwóch analityków, którzy pracują niezależnie. Należy podać stopień zgodności (na przykład w postaci współczynnika kappa) między analitykami dokonującymi selekcji na etapie analizy pełnych tekstów publikacji.

Preferowaną metodą rozstrzygania niezgodności jest uzyskiwanie konsensusu. W odpowiednich miejscach opracowania należy podać inicjały analityków wykonujących poszczególne zadania. Analiza powinna przejrzyście informować o liczbie dostępnych doniesień naukowych na poszczególnych etapach wyszukiwania i selekcji badań. Proces prowadzący do ostatecznej selekcji należy przedstawić w postaci diagramu zgodnego z zaleceniami PRISMA $[11,12]$. Powinno się także przedstawić przyczyny wykluczenia badań na poszczególnych etapach selekcji oraz szczegółowe przyczyny wykluczenia - w przypadku publikacji ocenianych na podstawie pełnego tekstu. Wszystkie skale i kwestionariusze powinny być przedstawione w załącznikach do przeglądu systematycznego [5, 11-13].

\section{Źródła danych}

Należy wstępnie określić, jakie źródła danych zostaną przeszukane. W celu przeprowadzenia kompleksowego przeszukania konieczne może być uwzględnienie: baz specjalistycznych czasopism, katalogów bibliotecznych, materiałów wideo i zbiorów wyspecjalizowanych bibliotek. Przy ustalaniu źródeł informacji można skorzystać z porad bibliotekarza, archiwisty, kolegów i osób nadzorujących pracę [9].

\section{„Szara literatura”}

Termin „szara literatura” odnosi się do materiałów, które zostały opublikowane w źródłach nierecenzowanych. Tego typu publikacje mogą stanowić wartościowe źródło wiedzy na przykład na temat danych historycznych.

Przykłady ,szarej literatury” to: materiały konferencyjne, prace dyplomowe, dokumenty rządowe, ulotki i biuletyny, roczne raporty, dokumenty biznesowe, blogi, podcasty; broszury; raporty; artykuły z gazet [9]. 


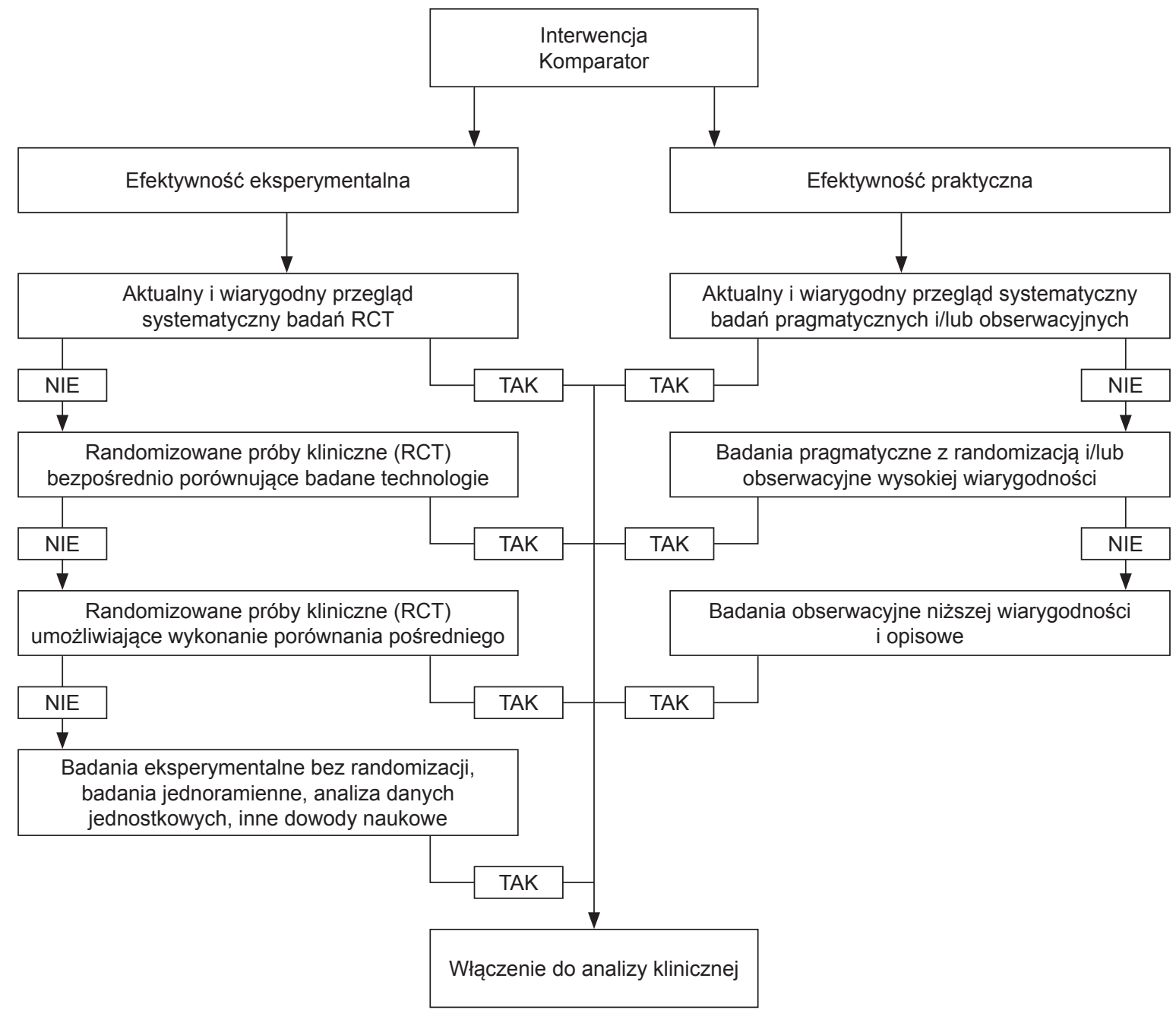

Rysunek 1. Algorytm postepowania w selekcji i właczaniu badań do analizy klinicznej

Źródto: Wytyczne AOTMiT 2016, http://www.aotm.gov.pl/www/wp-content/uploads/wytyczne_hta/2016/20160913_Wytyczne_ AOTMiT.pdf (dostęp: 11.06.2019) [5].

\section{Ocena wiarygodności źródeł oraz krytyczna ocena publikacji}

W trakcie wyszukiwania wartościowych i wiarygodnych informacji należy brać pod uwagę ich aktualność, źródło (czasopismo, konferencja, autorzy, instytucje), obiektywność/niezależność oraz dokładność.

Dokładność:

- Czy informacja jest wiarygodna?

- Czy informacja jest pozbawiona błędów?

- Czy informacja została prawidłowo uzasadniona/ udowodniona?

- Czy możliwa jest weryfikacja informacji na podstawie innych wiarygodnych źródeł?

Źródło:

- Kim są autorzy?

- Czy są wykwalifikowani do przedstawiania informacji na temat danego zagadnienia?

- Czy są powiązani z renomowanymi uczelniami/instytucjami/organizacjami zajmującymi się danym zagadnieniem?

- Czy źródło danych jest recenzowane/oceniane?
Obiektywność:

- W jakim celu opublikowano daną informację/ materiały?

- Czy informacja jest popartym dowodami faktem, czy stanowi opinię?

- Czy informacja jest obarczona ryzykiem?

- Czy można to ryzyko oszacować?

Aktualność:

- Kiedy informacja została opublikowana?

- Czy informacja jest aktualna czy przestarzała?

- Czy aktualność ma znaczenie dla danego zagadnienia? Ocena przydatności/akuratności informacji:

- Czy informacja zaspokaja/wyczerpuje/obejmuje całość zagadnienia?

- Czy informacja zawiera dane podstawowe, czy zgłębia dane zagadnienie?

Należy sprawdzić, czy do danego typu informacji/ publikacji/materiałów zostały przygotowane specyficzne kwestionariusze/skale do oceny ich wiarygodności/ wartości (na przykład ocena ryzyka błędu systematycznego zgodnie z Cochrane Handbook, skale AMSTAR/ AMSTARII do metaanaliz i przeglądów systematycznych, 
skala GRADE do oceny jakości dowodów i siły rekomendacji). Zastosowanie uniwersalnych skal i kwestionariuszy pozwala na porównanie wiarygodności informacji $\mathrm{z}$ różnych źródeł $[3,8,14]$.

\section{Instrukcja pisania przeglądów systematycznych}

Przed przystąpieniem do pracy nad przeglądem systematycznym należy spokojnie rozważyć, czy jest on konieczny, i odpowiedzieć na następujące pytania:

- Czy pytanie badawcze (cel przeglądu systematycznego) jest jednoznacznie i precyzyjnie zdefiniowane? $\mathrm{Na}$ podstawie pytania badawczego przygotowywana jest strategia wyszukiwania, kryteria włączenia i wyłączenia dowodów naukowych oraz typ danych (na przykład punkty końcowe), których użyjesz w przeglądzie. $Z$ tego powodu pytanie powinno być precyzyjne i jasno zdefiniowane, tak aby umożliwić zastosowanie metody naukowej (wnioskowanie na podstawie dowodów, z jednoczesnym wykluczaniem wszelkich innych możliwości) i przejrzystość.

- Czy przygotowano protokół, z pomocą którego zostaną stworzone właściwe strategie wyszukiwania, pozwalające na przeprowadzenie dokładnego i systematycznego poszukiwania źródeł informacji? W protokole są opisane poszczególne etapy przygotowania przeglądu systematycznego: określenie metodologii wyszukiwania, kryteriów włączenia i wyłączenia, inne filtry/zawężenia.

- Czy nad przeglądem będzie pracował prawidłowo dobrany zespół, w którego skład wejdą: eksperci z danej dziedziny, dwóch lub więcej recenzentów publikacji, specjalista do spraw informacji/bibliotekarz, statystyk zapewniający niezbędne wsparcie na poszczególnych etapach prac? Celem takiego zespołu będzie:

- odnalezienie za pomocą strategii wyszukiwania potencjalnie użytecznych badań;

- selekcja materiałów/badań/publikacji na podstawie wcześniej zdefiniowanych kryteriów włączenia i wyłączenia;

- krytyczna ocena włączonych materiałów/badań/ publikacji;

- analiza i interpretacja odnalezionych wyników/ rezultatów;

- publikacja opracowania $\mathrm{z}$ wynikami przeglądu systematycznego.

- Czy ekstrakcja i obróbka danych zostały przeprowadzone prawidłowymi narzędziami? Ekstrakcją danych powinno zajmować się co najmniej dwóch badaczy. Zmniejsza to ryzyko popełnienia błędu.

- Czy na przygotowanie przeglądu systematycznego zarezerwowano wystarczającą ilość czasu? Zwykle przygotowanie tego typu raportu zajmuje od 18 do 24 miesięcy.

- Czy przyjęto metody oceny i minimalizacji błędów (bias)? Istnieje wiele rodzajów błędów, na przykład selekcji, raportowania, wykonania. Ocena ryzyka błędu każdego z włączonych badań/publikacji jest bardzo ważnym etapem przygotowania przeglądu systematycznego.
- Czy stać cię na tłumaczenie publikacji z języków innych niż twój rodzimy i angielski? Do przeglądu systematycznego powinny zostać włączone wszystkie odnalezione materiały spełniające kryteria włączenia, niezależnie od języka publikacji [15].

\section{Zasady przygotowania strategii wyszukiwania}

\section{Prace wstępne}

Strategia wyszukiwania powinna zostać opracowana odpowiednio do zdefiniowanego problemu decyzyjnego oraz być zgodna z zaleceniami Cochrane Handbook oraz Centre for Reviews and Dissemination (CRD) wskazanymi przez EUnetHTA, dotyczącymi prawidłowego przeprowadzenia przeglądu systematycznego. Zaleca się stosowanie strategii wyszukiwania o możliwie najwyższej czułości. Jedynie w przypadku dużej liczby trafień można zwiększać swoistość przeszukiwania kosztem jego czułości. Jeżeli w poszczególnych bazach zastosowano strategie różniące się istotnie czułością, wymagane jest uzasadnienie takiego postępowania. Kryteria wyszukiwania powinny uwzględniać elementy schematu PICO. W strategii wyszukiwania nie zaleca się stosowania słów kluczowych odnoszących się do punktów końcowych. Rezultatem końcowym wyszukiwania powinno być zgromadzenie wszystkich dostępnych badań i danych niezbędnych do wykonania rzetelnej oceny efektywności [5].

\section{Etapy opracowywania strategii wyszukiwania}

Strategia wyszukiwania jest to dobrze przemyślany i jednoznacznie sformułowany plan dotyczący odnalezienia wiarygodnych informacji na dany temat. Przeszukanie różnych źródeł informacji na podstawie wcześniej przyjętych założeń pozwala na dużą oszczędność czasu.

W celu przygotowania strategii wyszukiwania należy:

1. zdefiniować i zapisać pytanie badawcze - czego będziesz poszukiwał (w HTA najczęściej jest to PICO);

2. odnaleźć słowa kluczowe, charakterystyczne wyrażenia i terminy;

3. odnaleźć synonimy dla powyższych;

4. określić okres przeszukiwania $-\mathrm{z}$ jakiego okresu poszukujemy badań;

5. rozważyć, jakiego typu badania będą włączane wraz z uzasadnieniem;

6. określić, gdzie będzie przeprowadzane wyszukiwanie informacji - w jakich bazach danych/wydawnictwach/czasopismach/bibliotekach [7].

\section{Zapisywanie strategii wyszukiwania}

W opisie strategii wyszukiwania powinny się znaleźć informacje pozwalające na jej odtworzenie przez inną osobę i uzyskanie tożsamych wyników. W szczególności opis powinien zawierać: zapisane strategie wyszukiwania, źródła danych (na przykład bazy danych), w których je przeprowadzono, oraz wyniki poszczególnych wyszukiwań.

Opis powinien zawierać:

1. nazwy źródeł oraz platform (na przykład Medline via PubMed), za pomocą których uzyskano dostęp do danego źródła; 
2. strategie wyszukiwania $\mathrm{z}$ poszczególnych źródeł powinny zostać dodane w postaci załącznika do publikacji. Powinny one zawierać szczegółowe informacje o:

a. sposobie wyszukiwania (przeszukane pola publikacji, użycie słownika);

b. użytych w trakcie wyszukiwania hasłach i synonimach;

c. użytych dodatkowych funkcjach/algorytmach;

d. zapisanych operacjach logicznych wykonanych w trakcie wyszukiwania (OR/AND/NOT);

3. liczbę odnalezionych publikacji dla każdego zapytania z każdej z przeszukiwanych baz danych [7].

\section{Narzęuzia do tworzenia strategii wyszukiwania}

W trakcie przygotowywania strategii wyszukiwania należy korzystać z zaimplementowanych w bazach danych licznych narzędzi i funkcji, między innymi z:

- wbudowanych w bazy danych słowników (na przykład MeSH, Emtree);

- operatorów logicznych (OR, AND, NOT);

- znaków specjalnych (*, \$);

- narzędzi dodatkowych.

Część z nich jest używana za każdym razem (słowniki, operatory logiczne), natomiast inne można użyć w celu przyspieszenia/ułatwienia pracy.

\section{Rodzaje wyszukiwania}

W trakcie przygotowywania strategii wyszukiwania należy wykorzystywać dwa podstawowe algorytmy przeszukiwania zasobów baz danych: wyszukiwanie wolnotekstowe (ang. free-text search) oraz wyszukiwanie z zastosowaniem wbudowanych w bazę danych słowników.

Wyszukiwanie wolnotekstowe polega na wyszukiwaniu w zamieszczonych w bazie danych materiałach wpisanego w okno wyszukiwania ciągu znaków (np. słowa cancer). W trakcie wyszukiwania wolnotekstowego zwykle jest możliwe wskazanie części publikacji, w których wskazane przez nas hasła mają być wyszukiwane (na przykład: tytuł, abstrakt, słowa kluczowe, autorzy, nazwa czasopisma). Dzięki zawężeniu wyszukiwania wolnotekstowego do wybranych pól zwiększamy swoistość, lecz zmniejszamy czułość wyszukiwania. Przed przystąpieniem do wyszukiwania wolnotekstowego należy wcześniej zidentyfikować wszystkie najważniejsze synonimy, nazwy i skróty odnoszące się do poszczególnych elementów PICO uwzględnionych w strategii wyszukiwania, a następnie wyszukać je w bazie danych.

Wyszukiwanie $\mathrm{z}$ pomocą zaimplementowanych do baz danych słowników polega na odnalezieniu, a następnie włączeniu do procesu haseł słownikowych odpowiadających poszczególnym elementom PICO uwzględnionym w strategii wyszukiwania.

W trakcie przygotowywania strategii wyszukiwania należy jednocześnie stosować obie metody w odniesieniu do poszczególnych, uwzględnionych elementów PICO.

\section{Slowniki z baz danych}

Słownik MeSH (ang. Medical Subject Headings) jest zaimplementowany w bazach danych Medline i Cochrane Library.

W jego zasobach znajdują się następujące składniki:

- > 27000 deskryptorów/haseł głównych (ang. main heading);

- > 87000 askryptorów/haseł pobocznych (ang. entry terms);

- > 232000 terminów dodatkowych (ang. supplementary concept records);

- rozbudowany system określników (ang. subheadings);

- inne wbudowane narzędzia (Major Topic, MeSH hierarchy) [1,3].

Słowniki EmTree/Thesaurus jest zaimplementowany w bazie danych Embase. W jego zasobach znajdują się następujące składniki:

- > 71000 deskryptorów/haseł głównych (ang. preferred terms);

- 3000 zindeksowanych przyborów medycznych;

- włączone wszystkie hasła główne MeSH;

- rozbudowany system określników (ang. subheadings);

- inne wbudowane narzędzia (Focus, Explode) [2].

\section{Podstawowe operatory logiczne}

Podstawowymi operatorami używanymi w budowaniu strategii wyszukiwania są operatory logiczne reprezentujące główne operacje algebry/logiki Boole'a. Te operatory, zwane operatorami Boole'a, to OR, AND i NOT, reprezentujące odpowiednio alternatywę, koniunkcję i negację.

\section{$O R$}

W praktyce budowania strategii w EBM operatora OR można użyć do łączenia różnych kwerend wyszukiwania opisujących dany element PICO dotyczący na przykład:

- interwencji (lub komparatora) - różne nazwy produktu leczniczego, na przykład nusinersen OR spinraza;

- populacji, to jest alternatywne określenia nazwy jednostki chorobowej, na przykład SMA OR spinal muscular athrophy;

- różnych jednostek chorobowych, gdy poszukujemy informacji o skuteczności danej technologii w kilku jednostkach chorobowych, na przykład tuberculosis OR mycobacteriosis;

- punktów końcowych istotnych w danej jednostce chorobowej, jak na przykład progression free survival OR overall survival OR disease free survival;

- łączenia terminu ze słownika MeSH z wyszukiwaniem wolnotekstowym, na przykład gaucher disease OR “Gaucher Disease” [Mesh].

W wyniku użycia OR otrzymujemy sumę wszystkich kwerend wyszukiwania zawierających którekolwiek z wyszukiwanych wyrażeń (zob. Rysunek 2).

\section{AND}

Operator AND jest używany do łączenia poszczególnych elementów PICO, jak w przypadku wyszukiwania informacji dotyczących stosowania leku w danej populacji, 


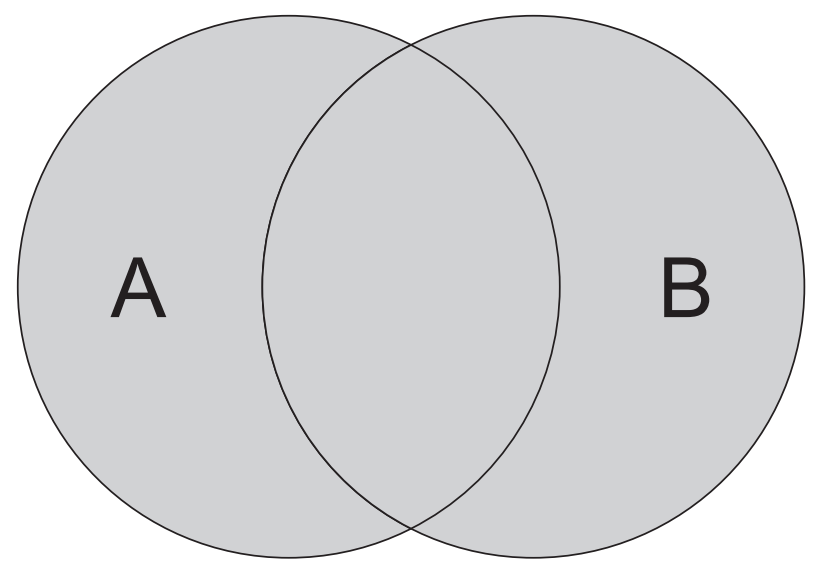

Rysunek 2. Graficzne przedstawienie dziatania operatora OR Źródto: Opracowanie własne.

na przykład rituximab AND rheumatoid arthritis. Może także służyć do uszczegółowiania populacji/jednostki chorobowej, na przykład tuberculosis AND multiple drug resistance.

W wyniku użycia AND otrzymujemy rezultat zawężony do tych publikacji, które zawierają jednocześnie wszystkie użyte w zapytaniu wyrażenia (część wspólną zbioru, zob. Rysunek 3).

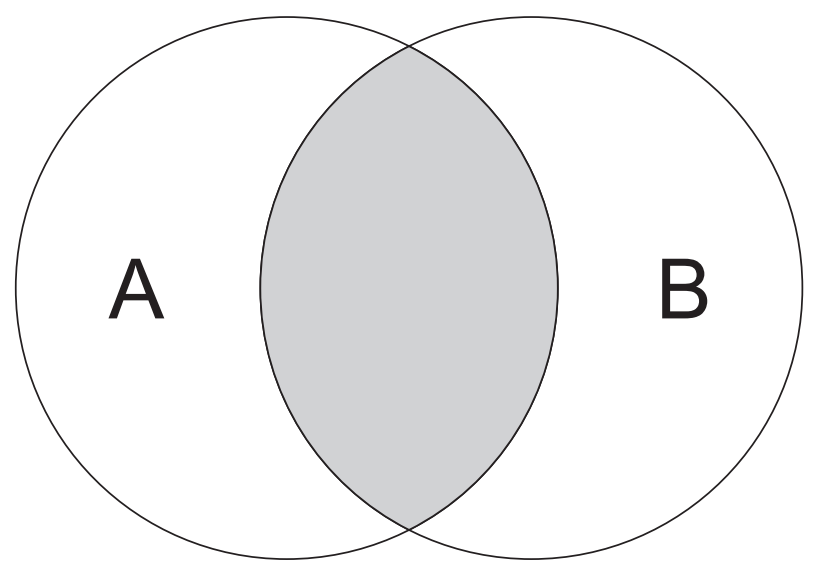

Rysunek 3. Graficzne przedstawienie działania operatora AND Źródto: Opracowanie własne.

\section{NOT}

Najrzadziej używanym z operatorów jest NOT. To operator wykluczający z zadanego zbioru rekordy zawierające daną frazę. W wyniku wyszukiwania humans NOT animals spośród wszystkich publikacji zawierających hasło humans zostaną wyłączone wszystkie rekordy, które zawierają przynajmniej jedno wyrażenie animals (zob. Rysunek 4). Przy użyciu tego operatora łatwo niezamierzenie wykluczyć wyniki odpowiadające zadanemu PICO (w wyżej wymienionym przykładzie badanie RCT w ludzkiej populacji docelowej, które w abstrakcie nawiązuje do wyników badań na zwierzętach), zalecane

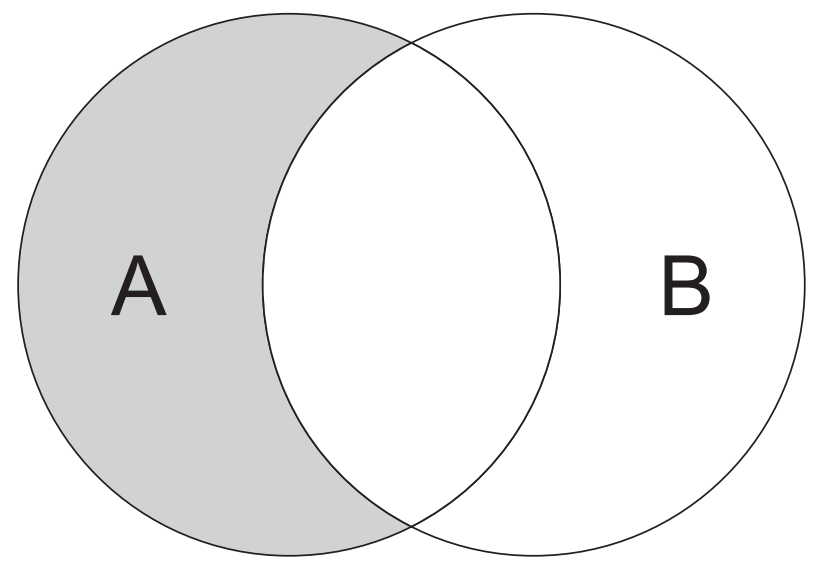

Rysunek 4. Graficzne przedstawienie działania operatora NOT Źródto: Opracowanie własne.

jest raczej użycie innych mechanizmów jako alternatywy. Co ciekawe, jak opisuje Sampson i wsp. [16], w celu zawężenia lepiej użyć fraz NOT (animals NOT $h u$ mans) zamiast wykluczania wszystkich rekordów indeksowanych jako animals lub ograniczania wyszukiwania do humans.

W Tabeli I zawarto opisy podstawowych operatorów z instrukcji baz Medline, Embase oraz Cochrane Library, omawianych w niniejszym artykule $[1,17,18]$.

\section{Dodatkowe operatory, funkcje i symbole specjalne}

\section{Operatory pozycji i częstości}

Część baz daje możliwość korzystania z operatorów pozycji, które wyszukują hasła w zadanym zakresie odległości od siebie. Działają one, gdy w pojedynczej kwerendzie wyszukiwania wpiszemy więcej niż jedno słowo/ciąg znaków. Hasła mogą znajdować się w dowolnej kolejności (z jednym wyjątkiem opisanym niżej). Zakres działania funkcji jest mierzony liczbą dodatkowych słów, które mogą się znaleźć między wpisanymi przez nas hasłami wyszukiwania. Operatory pozycji mogą zostać użyte zamiast operatora AND, co zwiększa precyzję wyszukiwania [16].

\section{Operator pozycji ADJn - Embase (via Ovid)}

W bazie Embase wyszukiwanie dwóch haseł za pomocą operatora ADJn jest ograniczone do maksymalnej odległości 99 słów od siebie. Wyszukiwane hasła rozdzielamy operatorem, gdzie pod $n$ wstawiamy dowolną liczbę z zakresu 1-99. W przypadku gdy użyjemy ADJ bez przypisania do niego wartości, baza będzie wyszukiwać dwa hasła przylegające do siebie w tej kolejności, w której zostały wpisane (bez dodatkowych słów między nimi). Przy użyciu ADJ1 będą wyszukiwane hasła przylegające do siebie w dowolnej kolejności, na przykład dla kwerendy skin cancer zostaną w bazie wyszukane: skin cancer oraz cancer skin. Wpisanie cancer ADJ2 skin (lub cancer ADJ3 skin, cancer ADJ4 skin,... itd.) będzie skutkować odnalezieniem wpisanych w pojedynczej kwerendzie wyszukiwania 


\begin{tabular}{|c|c|c|c|}
\hline $\begin{array}{l}\text { Operator } \\
\text { Boole'a }\end{array}$ & OR & AND & NOT \\
\hline $\begin{array}{l}\text { Embase } \\
\text { (via } \text { Ovid) }\end{array}$ & $\begin{array}{l}\text { Operator OR umożliwia uzyskanie } \\
\text { rekordów zawierających jakiekolwiek } \\
\text { z wyszukiwanych wyrażeń. Na przy- } \\
\text { kład przeszukiwanie heart attack OR } \\
\text { myocardial infraction zwraca rekordy, } \\
\text { które zawierają heart attack, myocardial } \\
\text { infraction lub oba te wyrażenia. Wynik } \\
\text { wyszukiwania obejmuje łącznie wszyst- } \\
\text { kie rekordy. }\end{array}$ & $\begin{array}{l}\text { Operator AND pozwala na uzyskanie } \\
\text { tylko tych rekordów, które zawierają } \\
\text { wszystkie wyszukiwane wyrażenia. } \\
\text { Na przykład przeszukiwanie blood } \\
\text { pressure AND stroke zwraca jedynie te } \\
\text { rekordy, które zawierają oba wyraże- } \\
\text { nia blood pressure i stroke w jednym } \\
\text { rekordzie. Wynik wyszukiwania nie } \\
\text { obejmuje rekordów, które nie zawierają } \\
\text { obu wyrażeń. }\end{array}$ & $\begin{array}{l}\text { Operator NOT pozwala na uzyskanie } \\
\text { rekordów, które zawierają pierwsze wy- } \\
\text { rażenie, ale wyłączają drugie wyrażenie. } \\
\text { W ten sposób można ograniczyć zakres } \\
\text { wyników. Na przykład wyszukiwanie } \\
\text { health reform NOT health maintenance } \\
\text { organizations zwraca jedynie te wyniki, } \\
\text { które zawierają wyrażenie health reform, } \\
\text { ale wykluczą spośród nich rekordy za- } \\
\text { wierające wyrażenie health maintenance } \\
\text { organizations. } \\
\text { Operatora NOT należy ostrożnie używać } \\
\text { i kwestionować jego użycie, gdyż można } \\
\text { wyeliminować istotne artykuły. Przy- } \\
\text { kładowo, wyszukując jak wyżej, można } \\
\text { wykluczyć rekordy, które omawiają } \\
\text { jednocześnie zagadnienia związane } \\
\text { z reformą zdrowia i organizacjami opieki } \\
\text { zdrowotnej. }\end{array}$ \\
\hline \multirow[t]{2}{*}{$\begin{array}{l}\text { Medline } \\
\text { (via } \text { Pubmed) }\end{array}$} & $\begin{array}{l}\text { OR zwraca wyniki, które włączają } \\
\text { przynajmniej jedno z wyszukiwanych } \\
\text { wyrażeń. }\end{array}$ & $\begin{array}{l}\text { AND zwraca wyniki, które zawierają } \\
\text { wszystkie wyszukiwane wyrażenia. }\end{array}$ & $\begin{array}{l}\text { NOT wyklucza zwracane wyrażenia } \\
\text { z wyszukiwania. }\end{array}$ \\
\hline & \multicolumn{3}{|c|}{$\begin{array}{l}\text { Operatory Boole’a muszą być używane w połączeniu z oznaczaniem pól wyszukiwania haseł w następujący sposób: } \\
\text { hasto [tag] operator Boole'a hasto [tag]. }\end{array}$} \\
\hline \multirow[t]{2}{*}{$\begin{array}{l}\text { Cochrane } \\
\text { Library }\end{array}$} & $\begin{array}{l}\text { Co najmniej jedno z wyrażeń musi po- } \\
\text { jawić się w artykule lub wybranym polu } \\
\text { przeszukiwania. } \\
\text { Przykład: heart OR cardiac }\end{array}$ & $\begin{array}{l}\text { Oba wyrażenia muszą się poja- } \\
\text { wić w artykule lub wybranym polu } \\
\text { przeszukiwania. } \\
\text { Przykład: insulin AND diabetes }\end{array}$ & $\begin{array}{l}\text { Pierwsze słowo musi się pojawić, } \\
\text { ale drugie słowo nie może pojawić } \\
\text { się w artykule lub wybranym polu } \\
\text { przeszukiwania. } \\
\text { Przykład: aids NOT hearing }\end{array}$ \\
\hline & \multicolumn{3}{|c|}{$\begin{array}{l}\text { Jeśli wyszukiwana fraza zawiera więcej niż jeden operator Boole’a bez zastosowania grupowania wyrażeń (za pomocą nawia- } \\
\text { sów, ang. nesting), system wyszukiwania rozpatruje operatory w następującej kolejności - jako pierwsze wszystkie operatory } \\
\text { NOT, w drugiej kolejności operatory AND oraz na końcu operatory OR. Dla lepszej precyzji wyszukiwania należy stosować } \\
\text { grupowanie, aby sprecyzować kolejność operacji. }\end{array}$} \\
\hline
\end{tabular}

Tabela I. Opisy operatorów Boole'a i wybrane informacje dodatkowe zawarte w instrukcjach omawianych baz

Źródło: Opracowanie własne na podstawie: Pubmed Help, https://www.ncbi.nlm.nih.gov/books/NBK3827/\#pubmedhelp (dostęp: 1.07.2019) [1]; Ovid Guide, http://site.ovid.com/site/help/documentation/osp/en/Content/syntax.htm\#truncation (dostęp: 1.07.2019) [17]; Cochrane Search Help, https://www.cochranelibrary.com/advanced-search/search-manager (dostep: 1.07.2019) [18].

haseł w dowolnej kolejności lub rozdzielonych maksymalnie jednym słowem (ADJ2) albo dwoma słowami (ADJ3), ewentualnie maksymalnie trzema słowami (ADJ4). Przykładowo patient ADJ6 relationship włącza do wyników takie frazy, jak physician patient relationship, patient physician relationship, relationship of the physician to the patient itd. [17].

Używając operatora pozycji, warto sprawdzić w przewodniku danej bazy, czy nie używa listy słów, które będą ignorowane w liczeniu odległości między hasłami. Są to takie słowa, jak na przykład $a$, the lub is, w Ovid są one określone jako stop words. Konstruując strategię z użyciem operatora pozycji, należy wziąć pod uwagę, czy baza liczy te słowa, i rozważyć zwiększenie (lub zmniejszenie) liczby słów o 2 lub 3 [17].

Operatory pozycji NEAR, NEAR/X, NEXT - Cochrane Library Podobną funkcję do wyżej wymienionego operatora $\mathrm{w}$ bazie Cochrane Library pełnią operator NEAR, NEAR/X oraz NEXT. Mechanizm działania operatora różni się jednak w pewnym stopniu od wyżej opisanego operatora ADJn. Wpisanie NEAR między hasła będzie skutkować wyszukiwaniem rekordów, w których te hasła znajdują się w odległości do 6 słów od siebie, w dowolnej kolejności, na przykład skin NEAR cancer zwraca zarówno wyrażenia skin cancer, jak i cancer of the skin czy cancer that arise from the skin. Istnieje również możliwość określenia maksymalnej liczby słów, która może znajdować się między wyszukiwanymi hasłami. W operatorze NEAR/X pod $X$ podstawiamy żądaną maksymalną liczbę słów, które mogą się znaleźć między członami naszej kwerendy wyszukiwania, na przykład cancer NEAR/3 lung odnajduje zarówno lung cancer, jak i cancer of the lung [18].

Ostatni z nich, operator NEXT, wpisany między słowami ma działanie tożsame z ADJ z bazy Embase (via OVID), to jest wyszukuje hasła przylegające do siebie w tej kolejności, w której zostały wpisane [18].

\section{Operator częstości - Embase (via Ovid)}

Użycie tego operatora pozwala na wyciągnięcie z bazy rekordów, które będą zawierały z określoną częstością 
wyszukiwane hasło. Wymagana częstość określana jest przez próg w komendzie ,hasło.xy./freq=n”, gdzie wartość progu podstawiana jest pod $n$, a pod $x y-$ dwuliterowy kod pola ${ }^{1}$, w którym występowanie hasła będzie liczone. W wyniku zadanego wyszukiwania breast cancer.tx./freq $=\mathbf{5}$ otrzymanym rezultatem będą jedynie te rekordy, które zawierają hasło breast cancer przynajmniej pięć razy w polu Full Text. Operator ten nie daje możliwości przeszukiwania w kilku polach jednocześnie, wpisanie komendy breast cancer.ti,ab./freq=5 skutkuje zwróceniem komunikatu o błędzie [17].

\section{Symbole wieloznaczne}

Symbole wieloznaczne stanowią użyteczne narzędzie pozwalające $\mathrm{w}$ określonych sytuacjach na ułatwienie i przyspieszenie pracy nad strategią wyszukiwania. Poniżej przedstawiono krótkie opisy symboli wieloznacznych występujących w poszczególnych bazach danych wraz z opisem zasad ich stosowania.

\section{Symbole wieloznaczne - Embase (via Ovid)}

Dowolny pojedynczy znak obligatoryjny w wyszukiwaniu zastępujemy znakiem ,\#”. Znak może być wykorzystany zarówno w środku, jak i na końcu słowa, na przykład wom\#n wyszukuje woman oraz women, dla dog\# wynikiem jest $\operatorname{dogs}$, ale nie dog ani nie dogma [17].

Symbol wieloznaczny „?” zastępuje jeden znak lub jego brak (symbol opcjonalny). Może być użyty zarówno na końcu słowa, jak i w środku. Szczególnie przydatny w przypadku wyszukiwania wariantów haseł, które mają różną pisownię w brytyjskim i amerykańskim angielskim, na przykład wpisanie colo?r skutkuje wyszukaniem zarówno słowa color, jak i colour [17].

Symbolami wieloznacznymi używanymi na końcu wyrazu są „"” oraz „\$”, które zastępują dowolną liczbę znaków następujących po „rdzeniu” hasła, przykładowo gene* $^{*}$ zwraca zarówno słowo gene, jak i słowa genes, genetic, generally itd. Liczbę symboli, które będą brane pod uwagę, można ograniczyć, wpisując hasło\$ $<\mathbf{n}>$, gdzie pod $n$ podstawiana jest żądana maksymalna liczba symboli, na przykład wyszukiwanie cancer $\$ 2$ znajduje występujące słowa cancer, cancers, canceric, ale nie cancerous [17].

\section{Symbole wieloznaczne - Cochrane Library}

W bazie Cochrane dostępne są symbole wieloznaczne „"” oraz ,??, które można używać zarówno na początku, końcu, jak i w środku hasła „rdzenia” (jednakże musi mieć ono minimum trzy znaki). Symbol „," zastępuje dowolną liczbę znaków następujących po „rdzeniu” hasła, na przykład transplant* identyfikuje słowa: transplant, transplants, transplanting, transplantation czy transplantable, *glycemia może reprezentować zarówno hyperglycemia, jak i hypoglycemia, a leuk*mia odnajduje słowa leukemia i leukaemia. Symbol „?” będzie używany podobnie, jak opisano wyżej dla bazy Embase, będzie zastępować jeden znak lub jego brak, na przykład system? dopasuje słowa system lub systems, ale nie systematic lub systemic [18].

\section{Symbole wieloznaczne - Medline (via Pubmed)}

Wyszukiwanie w PubMed daje możliwość skorzystania z symbolu „," na końcu wyszukiwanego słowa. Symbol ten funkcjonuje podobnie jak we wcześniej opisanych bazach, reprezentuje dowolną liczbę znaków. W przypadku gdy słowo z użyciem tego operatora daje więcej niż 600 możliwych wersji hasła, PubMed wyszukuje tylko pierwszych 600 wersji i wyświetla komunikat ostrzegający, by wydłużyć „rdzeń” hasła w celu wyszukania wszystkich możliwych wersji hasła [1].

Poniżej w Tabeli II przedstawiono podsumowanie operatorów i symboli omawianych w niniejszym artykule, w podziale na dostępność w opisywanych bazach danych.

\section{Najczęstsze problemy przy strategiach wyszukiwania i sposoby ich rozwiązania}

Poniżej przedstawiono kilka najczęściej występujących problemów oraz propozycje ich rozwiązań. Powstały one na podstawie wieloletniego doświadczenia w przeprowadzaniu strategii wyszukiwania przez pracowników agencji. Strategie wyszukiwania nie są typem pracy, którą wykonuje się każdego dnia. W związku z powyższym najczęstszym problemem jest obsługa interfejsów poszczególnych baz danych. W celu przypomnienia sobie sposobu korzystania z poszczególnych funkcji i narzędzi z danej bazy danych należy zapoznać się dostępnymi na każdej platformie instrukcjami, narzędziami treningowymi

\begin{tabular}{|c|c|c|c|c|}
\hline \multicolumn{2}{|c|}{ Operator/symbol } & Embase (via Ovid) & Cochrane Library & PubMed \\
\hline \multicolumn{2}{|c|}{ Operatory Boole'a } & \multicolumn{3}{|c|}{ OR, AND, NOT } \\
\hline \multicolumn{2}{|c|}{ Operatory pozycji } & $\mathrm{ADJ}, \mathrm{ADJ} n$ & NEAR, NEAR/ $X$, NEXT & brak \\
\hline \multicolumn{2}{|c|}{ Operator częstości } & FREQ & \multicolumn{2}{|c|}{ brak } \\
\hline \multirow{3}{*}{$\begin{array}{l}\text { Symbole } \\
\text { wieloznaczne }\end{array}$} & dowolna liczba znaków & $*, \$, \$ n$ (prawostronne skracanie) & * (dowolne umiejscowienie) & * (prawostronne skracanie) \\
\hline & $\begin{array}{l}\text { dozwolony znak } \\
\text { pojedynczy }\end{array}$ & ? (środek lub koniec wyrazu) & ? (dowolne umiejscowienie) & brak \\
\hline & $\begin{array}{l}\text { obligatoryjny pojedynczy } \\
\text { znak }\end{array}$ & \# (środek lub koniec wyrazu) & \multicolumn{2}{|c|}{ brak } \\
\hline
\end{tabular}

Tabela II. Rodzaje wybranych operatorów i symboli wieloznacznych dostęnych w bazach danych

Źródło: Opracowanie własne na podstawie Neyt M., Chalon P.X., Search MEDLINE for Economic Evaluations: Tips to Translate an OVID Strategy into a PubMed One, ,PharmacoEconomics” 2013; 31: 1087-1090 (dostep: 1.07.2019) [19]. 
i szkoleniowymi. W trakcie przeprowadzania strategii wyszukiwania bardzo trudno jest sprawdzić, czy nie popełniamy w jego takcie jakichś błędów. Dodatkowo należy pamiętać, że same bazy danych również popełniają błędy. Aby je wykrywać oraz zmniejszyć ryzyko ich występowania, należy zwracać uwagę na następujące rzeczy:

- przed przystąpieniem do przygotowania strategii wyszukiwania należy zapoznać się z podstawową wiedzą na temat interesującego nas zagadnienia. Przydatna jest wiedza na temat charakteru choroby (na przykład czy jest to choroba rzadka/ultrarzadka) oraz interwencji (w jakich wskazaniach jest stosowana, technologia innowacyjna/stosowana od dawna, postać farmaceutyczna). Ta wiedza ułatwia wykrywanie błędów w trakcie wyszukiwania (na przykład znajdowanie zbyt małej/ dużej liczby wyników względem oczekiwanej);

- w trakcie przeprowadzania strategii wyszukiwania najlepiej jest podzielić prace na etapy i przeprowadzać wyszukiwania w usystematyzowany sposób, na przykład zgodnie z przygotowanym wcześniej PICO - najpierw wyszukiwanie dla populacji, następnie dla interwencji itd;

- po wykonaniu każdego pojedynczego wyszukiwania należy spojrzeć na liczbę odnalezionych publikacji i ją krótko przeanalizować. Czy otrzymana liczba wyników jest zgodna z oczekiwaniami - jeżeli zapytanie o hasło ze spodziewaną dużą liczbą wyników (na przykład cancer) daje bardzo mało wyników, należy sprawdzić, czy nie popełniło się tak zwanej literówki w wyszukiwaniu;

- wyszukiwanie publikacji dla poszczególnych elementów PICO należy przeprowadzić w każdej z baz danych za pomocą wyszukiwania wolnotekstowego oraz słownikowego. Po wykonaniu wszystkich wyszukiwań wolnotekstowych dotyczących danego elementu PICO należy je między sobą połączyć za pomocą operatora OR, tak aby uzyskać wszystkie wyniki wyszukiwania wolnotekstowego dla danego elementu PICO w jednym wierszu. Następnie ten wiersz należy połączyć za pomocą operatora OR z wierszem wyszukiwania słownikowego dotyczącego tego samego elementu PICO i przeanalizować wynik tej operacji - sprawdzić, w jakim stopniu oba zbiory na siebie nachodzą. Zarówno w trakcie wyszukiwania wolnotekstowego, jak i słownikowego poszukujemy publikacji dotyczących tego samego zagadnienia, w związku z czym oba wyszukiwania powinny na siebie zachodzić. Błędem jest, jeżeli po połączeniu za pomocą operatora OR wyszukiwania wolnotekstowego (dającego na przykład 100 wyników) i słownikowego (dającego na przykład 150 wyników) otrzymamy ich sumę (w tym przypadku 250 wyników), gdyż oznacza to, że te zbiory w ogóle na siebie nie zachodzą. Jeżeli taka sytuacja występuje, należy sprawdzić, czy użyliśmy prawidłowych haseł wyszukiwania wolnotekstowego (literówki) oraz czy prawidłowo dobraliśmy uwzględnione w wyszukiwaniu hasło słownikowe;

- w trakcie wyszukiwania po zastosowaniu operatorów logicznych należy sprawdzać, czy uzyskane wyniki są zgodne z oczekiwaniami. Po zastosowaniu funkcji
AND dla dwóch lub większej liczby wierszy wyszukiwania (liczących na przykład 100 i 150 wyników) nigdy nie powinniśmy uzyskać liczby wyników wyższej niż najniższy z wyników włączonych do operacji (w tym przypadku nie więcej niż 100 wyników). Po zastosowaniu funkcji OR dla dwóch lub większej liczby wierszy wyszukiwania (liczących na przykład 100 i 150 wyników) nigdy nie powinniśmy uzyskać liczby wyników mniejszej niż najwyższy z wyników włączonych do operacji (w tym przypadku nie mniej niż 150 wyników). Jeżeli w wyniku zastosowania operatora logicznego otrzymujemy wynik niezgodny z zasadą działania danego operatora (na przykład po zastosowaniu OR dla dwóch wierszy wyszukiwania liczących odpowiednio 1000 i 1500 wyników otrzymujemy 500), oznacza to błędne działanie bazy danych. Jeżeli sytuacja się powtarza po powtórnym wykonaniu operacji, oznacza to, że problemy występują po stronie bazy danych. W takiej sytuacji najlepiej zapisać dotychczasową pracę, a do wyszukiwania powrócić w późniejszym terminie;

- w przypadku popełnienia błędu w wierszu wyszukiwania (na przykład zrobienie literówki) nie należy usuwać błędnego wiersza ze strategii wyszukiwania. Usuwanie wierszy ze strategii wyszukiwania, zwłaszcza w sytuacji gdy jest ona długa (na przykład 20-30 wierszy), często prowadzi do występowania błędów po stronie bazy danych i konieczności powtarzania całego procesu. Wiersz z błędem należy pominąć w trakcie łączenia z prawidłowymi wierszami wyszukiwania (na przykład podczas łączenia za pomocą OR wierszy dotyczących danego elementu PICO);

- po wykonaniu strategii wyszukiwania użytkownik pobiera na swój komputer listę odnalezionych abstraktów. Po ściągnięciu takiego pliku należy nadać mu odpowiednią nazwę, która pozwoli na identyfikację źródła pliku (z jakiej bazy danych pochodzi) oraz tematu wyszukiwania (populacja, interwencja).

\section{Podsumowanie}

Celem niniejszego opracowania było przedstawienie podstawowych zagadnień związanych z przygotowywaniem strategii wyszukiwania oraz przeglądów systematycznych na potrzeby raportów EBM/HTA. Przedstawiono $\mathrm{w}$ nim instrukcje $\mathrm{z}$ odnalezionych wytycznych metodologicznych oraz definicje i porady dotyczące podstawowych funkcji oraz narzędzi wyszukiwania. Mamy nadzieję, że po zapoznaniu się z treścią powyższego artykułu samodzielne wykonywanie strategii wyszukiwania oraz przeglądów systematycznych stanie się łatwiejsze i bardziej przejrzyste.

\section{Przypisy}

${ }^{1} \mathrm{~W}$ basie Embase są to dwuliterowe kody identyfikujące poszczególne pola, w których zawiera się opis rekordu w bazie, jak na przykład tytuł (ti), abstrakt (ab), autorzy (au) itd. Bazy Cochrane Library oraz Medline również posiadają specyficzne dla siebie kody przypisane do takich pól. 


\section{Piśmiennictwo}

1. Pubmed Help, https://www.ncbi.nlm.nih.gov/books/NBK3827/\#pubmedhelp (dostęp: 1.07.2019).

2. Embase Learn and Support, https://www.elsevier.com/ solutions/embase-biomedical-research/learn-and-support (dostęp: 1.07.2019).

3. Cochrane Polska, https://poland.cochrane.org/pl/jak-interpretowa $\% \mathrm{C} 4 \% 87$-przeg $1 \% \mathrm{C} 4 \% 85 \mathrm{dy}$-systematyczne (dostęp: 1.07.2019).

4. Murad M.H., Montori V.M., Ioannidis J.P. et al., How to read a systematic review and meta-analysis and apply the results to patient care: users' guides to the medical literature, „JAMA: The Journal of the American Medical Association ” 2014; 312 (2): 171-179.

5. Wytyczne AOTMiT 2016, http://www.aotm.gov.pl/www/ wp-content/uploads/wytyczne_hta/2016/20160913_Wytyczne_AOTMiT.pdf (dostęp: 11.06.2019).

6. Charles Sturt University 1, https://libguides.csu.edu.au/c. php?g=476545\&p=3997202 (dostęp: 12.07.2019).

7. Charles Sturt University 2, https://libguides.csu.edu.au/c. php? $\mathrm{g}=476545 \& \mathrm{p}=4949988$ (dostęp: 4.06.2019).

8. Charles Sturt University 3, https://libguides.csu.edu.au/c. php?g=476545\&p=4833434 (dostęp: 1.07.2019).

9. Charles Sturt University 4, https://libguides.csu.edu.au/c. php?g=476545\&p=3826737 (dostęp: 22.07.20190).

10. Pittway (2008), Systematic literature reviews, w: Thorpe R., Holt R., The SAGE Dictionary of Qualitative
Management Research, SAGE Publications Ltd., London 2008, doi:10.4135/9780857020109.

11. Liberati A., Altman D.G., Tetzlaff J. et al., The PRISMA statement for reporting systematic reviews and metaanalyses of studies that evaluate health care interventions: Explanation and elaboration, „Annals of Internal Medicine” 2009; 151: W65-W94.

12. Moher D., Liberati A., Tetzlaff J. et al., Preferred reporting items for systematic reviews and meta-analyses: The PRISMA statement, „Annals of Internal Medicine” 2009; 151: 264-269.

13. EUnetHTA Guidelines: Process of information retrieval for systematic reviews and health technology assessments on clinical effectiveness, July 2015.

14. Skala AMSTAR, https://amstar.ca/Amstar-2.php (dostęp: 21.07.2019).

15. University of Michigan Library, https://guides.lib.umich. edu/sysreviews (dostęp: 12.07.2019).

16. Sampson M., McGowan J., Cogo E. et al., An evidence-based prectice guideline for the peer review od lectronic search strategies, „Journal of Clinical Epidemiology” 2009; 62: 944-952.

17. Ovid Guide, http://site.ovid.com/site/help/documentation/ osp/en/Content/syntax.htm\#truncation (dostęp: 1.07.2019).

18. Cochrane Search Help, https://www.cochranelibrary.com/ advanced-search/search-manager (dostęp: 1.07.2019).

19. Neyt M., Chalon P.X., Search MEDLINE for Economic Evaluations: Tips to Translate an OVID Strategy into a PubMed One, ,PharmacoEconomics” 2013; 31: 1087-1090. 